\title{
PIPE CATOCA, AN EXAMPLE OF THE WEAKLY ERODED KIMBERLITES FROM NORTH-EAST OF ANGOLA
}

\author{
Ganga $^{1}$ J., Rotman' ${ }^{2}$ A.Ya., and Nosiko ${ }^{1}$ S. \\ ${ }^{1}$ Catoca Mining Company Ltd., Angola (nossykos@catoca.com) ${ }^{2}$ YaNIGP TsNIGRI ALROSA Co. Ltd, Chernyshevskiy Street \\ 7, Mirny, 678170, 678170, Russia
}

\section{INTRODUCTION}

Catoca pipe, which is located in the Catoca kimberlite field of the Lyuanda Norte Province, North-East of Angola, can be considered as a model of the wide range of weakly eroded diatrems founded in the region. These pipes are concentrated in the area of the Archaean basement consolidation (Craton Angola-Kassai) and their location controlled by the Lucapa regional faults zone of NE direction. The faults zone is $55-85 \mathrm{~km}$ wide and $1200 \mathrm{~km}$ long on the Angola territory, and can be traced for another $400 \mathrm{~km}$ on the territory of Zair, where position of kimberlite bodies are also related to this zone (Reis, 1972). In the South- West part of this structure a lots of pipe-shaped carbonatite bodies and alkaline rocks massives are present together with kimberlites. Carbonatite bodies can be easy diagnosed when they outcrop on the surface, but partly they are covered by siliceous breccias and fenitized rocks. As a rule, kimberlite pipes are located in the zones of the intersection of the NE and NW direction faults. The faults are linear basement dislocations accompanied by the system of the peripheral faults. The territory along the Luembe, Chiumbe, Luachimo and Chicapa rivers is the most well studied part of the Catoca field.

\section{LUANDA NORTE PROVINCE}

The Luanda Norte Province, where most of the Angolian diamond resources are concentrated (Araujo et al., 1988; 1998) includes four kimberlite fieldsCamazambo, Catoca, Camutue and Camatchia. At present time, more than 60 kimberlite bodies are known in these fields, 19 in Camazambo, 15 in Camutue, 8 in Camatchia and 25 in Catoca and there are good perspectives for discovery a new kimberlites. The plane shapes of the bodies are variable from the irregularlyrounded (Catoca, Camatchia) to significantly elongated in one direction (Camafuka-Camazambo) and sizes variable from the first tens of meters to hundreds meters in diameter reaching $900 \mathrm{~m}$ (Catoca pipe) and up to $3 \mathrm{~km}$ (Camafuka-Camazambo). These two above-mentioned pipes are between five of the world's biggest kimberlite bodies.
In the Camutue kimberlite field the most important are Camatue I (Western), Caixepa and Capombo pipes. Camatue I pipe is the biggest in the Camatue kimberlite field and have a size 500 by $200 \mathrm{~m}$ being elongated from SW to NE direction. Covered by the 20-30 m thick layer of Kalahari sands, the pipes only partly outcrops in the Rio-Camatue valley. The upper part of the pipe volume composed by the crater facies kimberlites about $100 \mathrm{~m}$ thick and only in the western part of the body there is outcrop of the diatreme facies rocks. These rocks are characterized by low diamond contents because they are significantly diluted by country rock fragments. However, the quality and average size of diamond is quite high, the stones up to 80ct are not rare. Cariue pipe is characterized by the very high concentration of heavy minerals, up to $100-250 \mathrm{~kg} / \mathrm{m} 3$. The sizes of the other pipes in Camutue field are poorly known.

The Camazambo kimberlite field includes one of the world biggest kimberlite pipe- Camafuka-Camazambo (Barget, 1973; Jance, 1995; Scott Smith, 1992) that has a square of 156 hectares. The rocks of the upper part of this diatreme are significantly diluted by Karoo sandstones, which make difficulties for a kimberlite diagnostic. The rocks of the diatreme facies are represented by the kimberlite breccias with significant amount of the country rocks fragments and partly by basaltic kimberlites containing garnet-clinopyroxene intergrowths. Diamonds and diamond indicator minerals of the pipe are recognized in the alluvium of the Chicapa River. In the $8 \mathrm{~km}$ to North and downstream Cagoa pipe is located, the upper part of which is composed by the diamondiferous xenotuffisitic breccias. The other pipes of this field have a similar structure to described above kimberlite bodies. Charackteric features of Camazambo field kimberlites are the elevated heavy minerals concentrations (up tom $50 \mathrm{~kg} / \mathrm{m} 3$ ), their wide paragenetic spectra and diosideilmenite-garnet indic ator minerals association.

\section{CATOKA PIPE}

As it is evident from the above description, practically all of the kimberlite pipes of the region are characterized by the preservation of their crater parts and Catoca pipe can be considered as an example of 
their structure features. In the Catoca kimberlite field, which is located in the southern part of the Luanda Norte Province (North-East of Angola), pipe Catoca is the biggest kimberlite body. The plane size of the pipe is $900 \mathrm{x} 900 \mathrm{~m}$ and square is $65.7 \mathrm{ha}$. The ganitegneisses and crystalline shists of Archaen age are country rocks of the pipe but overlying rocks are sediments of Kalahari formation and PaleogeneNeogene sands with the thickness from several meters to $130 \mathrm{~m}$. The diatreme part of the Catoca pipe has a complicated structure, similar to the Mwadui (Tanzania) and Orapa (Botswana) pipes, because of insignificant erosion and preservation of the crater complex. According to textural-genetic classification (Clement and Scinner, 1985; Mitchell, 1986) all types of kimberlite rocks (crater, diatreme and hypubyssal facies) are present in the body.

\section{Petrography}

Crater facies rocks show the wide variation on their composition and textural features and include sediments with little dilution by kimberlitic material, volcanicsedimentary and sediment-volcanic sequences. These rocks make up the tee-cup shaped body up to 230-270 $m$ deep from the present-day surface and lying with the washout unconformity on the diatreme facies rocks. In described genetical sequences several rocks varieties can be divided, depending on the groundmass and clastic fragments character. These varieties include the heterogeneous breccias (diluvial breccias, tuff breccias etc.) with the wide variation of fragments size, psephitic (gravelstones, tuff-gravelstones, tuffites, tuffs and xenotuffs), psammitic (sandstones, tuffitic sandstones, psammitic tuffites, tuffs and xenotuff), alevrolites and argillites, but the most common are fine-grained sandstones and varieties with mixed granulometric composition. The varieties can be distinguished by the amount of kimberlitic material they contain. This amount is insignificant in the epiclastic rocks but dominant in the sedimentary-volcanogec sequences. The characteristic features of the crater facies rocks are brownish color with a wide range of shades and layered textures. In the fine-grained sedimentary sequences (alevrolites and argillites) the layered textures are most evident. The boundaries between psephitic- psammitic sequences usually are gradual, but argillites have a contrast contacts with the other rocks varieties.

Below the heterogeneous rocks of crater facies the diatreme facies rocks are recognized. These rocks are represented by the eruptive kimberlite breccias with the brecciated, partly autholitic textures and massive texture of the groundmass. Breccias usually have a green-gray shadows of the color. The rocks have clastic and microclastic structures with a porphyric and clastoporphyric structured groundmass. They are characterized by hig h content of the autoliths (up to 40$50 \%$ of the rocks volume) and irregularly shaped fragments of the massive kimberlite (13-30\%). The autolith are rounded, isometric or ellipsoid shaped and have a clear concentrically zonation. The most common are the film type of autoliths with the cores represented by the pseudomorphed olivine macrocrysts, clinopyroxene or country rocks fragments. The amount of the xenogenic material (fragments of the crystalline basement) is not more than $25 \%$, being $5-7 \%$ of the rocks volume in the average. Fragments of gneisses, crystalline shales and granites practically almost altered to the weakly- anisotropic, layered mineral aggregate, carbonate (mostly dolomite), magnetite and iron hydroxides. Only small relicts of the amphibole, clinopyroxene and apatite remain unaltered. The groundmass of the breccias composed mainly by the serpentine-carbonate (dolomite) irregular mixture. Pseudomorphed olivine of second generation (microphenocrysts) occupied about 10-15\% of the rocks volume and they are characterized by broken shape and irregular distribution through the rocks. Altered to vermiculite phlogopite grains, perovskite crystals and opaque-oxide minerals are present in the groundmass which interstitial space composed by the subisotropic, fine-scales serpentine with the dolomite crystals spots.

The hypabussal facies kimberlites are represented by porphyric kimberlites, which make up the autolithic cores in the eruptive breccias, and rare separate fragments in the crater rocks of the Southern part of diatreme. It is proposed that hypabussal rocks are related to the two stages of the emplacement, the first and latest. These, which compose the emplacement channel and roots of the pipe, are related to the first stage and these located in the crater representing the latest stage of emplacement. Porphyric kimberlites contain a less country rocks fragments then other types of kimberlites, usually not more than 5-7\%. The hypabussal facies rocks have massive textures and microcrystalline, microporphyric structures. The porphyric olivine macrocrysts occupy about $10-15 \%$ of the rocks volume and mostly having ovoid shape, sometimes with the traces of resorption. The phlogopite of table- like shape and ilmenite, which partly altered to the polymineralic aggregates, make up the macrocrysts suite together with olivine. Up to $50 \%$ of the groundmass composed by euhedral and subhedral olivine crystals from 0.08 to $1.2 \mathrm{~mm}$ in size (mostly 0.3 $0.5 \mathrm{~mm}$ ), which are pseudomorphed to serpentine and serpentine-carbonate aggregate. They are regularly distributed, sometimes make up the glomeroporphyric intergrowth of several crystals. The bigger crystals $(0.8$ $1.2 \mathrm{~mm}$ ) totally pseudomorphed to fine-scaled subisotropic serpentine in association with magnetite, but lower size crystals $(0.1-0.5)$ mainly altered to 
calcite. Minor amounts of the phlogophite, crystals or intergrowth of variety of opaque oxide minerals (spinel, ilmenite, perovskite) and apatite crystals are also present. Total amount of the crystals in the groundmass are higher than that of glassy mesostasis.

The secondary and hypergene minerals compose the main part of Catoca pipe kimberlites volume. Serpentine, with domination of it's antigorite variety, is one of the most important of them in genetical relations. The montmorrilonite group minerals are also common in the rocks composition and presence of weakly crystallized montmorillonite -hydromica layered mixtures is characteristic feature of these rocks. With the depth the amount of smectite significantly decreases and amount of serpentine proportionally increases. The dispersed admixture of the quartz, iron oxides and hydroxides are usually present in the rocks.

\section{CHEMISTRY ANDMINERALOGY}

The wide variations of the concentrations of the major and trace elements are evident in the different facies rocks. The chemistry of the porphyric kimberlites and eruptive kimberlite breccias is more close to typical kimberlite composition then that of rocks of other varieties. Highest $\mathrm{SiO}_{2}$ concentration was detected in the volcanic-sedimentary rocks (average $\mathrm{SiO}_{2}$ content more than $65 \mathrm{wt}$ \%) and in the isolated sedimentary rocks samples (lack of visible kimberlite material) from the upper part of the section, possessed 54.67 to 79.04 wt. $\%$ at inverse correlation of $\mathrm{SiO}_{2}$ and $\mathrm{MgO}$. Upper parts, reach in clastic material are characterized by high silica concentrations, increased alkali concentrations $\left(\mathrm{Na}_{2} \mathrm{O}\right.$ and $\left.\mathrm{K} \mathrm{O}\right)$, sometimes of $\mathrm{Al}_{2} \mathrm{O}_{3}$, and decreased $\mathrm{MgO}$ ? $\mathrm{FeO}$ concentrations. Quantity of the two latter components remarkably increased whereas the former decreased with most contrast reduce of the $\mathrm{SiO}_{2}$ contents proceeding down to the mainly kimberlite lower part of the section. $\mathrm{TiO}_{2}$ lot is remarkably higher in the diatreme facies rocks. The concentrations of $\mathrm{Cr}$, $\mathrm{Ni}, \mathrm{Co}, \mathrm{Mn}, \mathrm{Zn}$ and $\mathrm{Sr}$ are notably higher, and $\mathrm{Ni} / \mathrm{Co}$ ratios are more than 10 in the diatreme facies rocks in comparison with crater rocks. The wide range of the concentration fluctuations indicates the extremely unbalanced (uneven) distribution of the trace elements in the analyzed rocks, which resulted from the great variations of the mineral composition.

It should be noted that almost the half of the diamond crystals possesses the octahedral habit (Krutchkov et al., 2000), the specimens with the transitional habit composed $31,3 \%$ of the total diamond population, and ? rhombic dodecahedrons $-17,5 \%$; the amount of plain verge octahedrons is $4,1 \%$. The imposed corrosion represented by the thin dull is characteristic for the $73,9 \%$ of diamonds. Monocrystals compile $65,8 \%$, the rest are intergrowth. The diamonds with singular cracks prevail. Most common are the diamonds with singular inclusions. They are represented by sulphids, chromespinel, pyropes that correspond to the ultrabasic paragenesis of the source rocks. The predominant peredotite (lherzolite) diamonds in the pipes of the mentioned province have been noted before (Boyd and Danchin, 1980). Noncolored stones and crystals with shadows prevail; colored diamonds are composed $19,7 \%$ of total population. Transparent stones compile $68,5 \%$, and only $2,4 \%$ of diamonds are nontransparent. The biggest diamond obtained so far by the GRO "Catoca" factory is 350,92 carats. On the whole diamonds from Catoca pipe can be assigned to the middle-high quality raw material, that allowed include the pipe into the leading group of the primary African diamond deposits. Analysis of the diamond distribution in the crater part of the Catoca pipe shows that the richest in diamond block (about $2 \mathrm{ct} /$ tonne) lies in the basement of the sedimentary strata filled the central part of the crater.

Except diamond, primary minerals like garnets, zircons, picroilmenites and clynopyroxenes practically are not altered whereas mica (phlogopite) is chloritized. The highest concentrations of the kimberlite indicator minerals and the heavy minerals fraction as a whole with the same amount of the pyrope and picroilmenite are recovered from the aperture facies rocks. Increased chromediopside quantity up to $13.7-22.3 \mathrm{wt}$. $\%$ was found in the epiclastic and volcanic-sedimentary rocks obtained from borehole 0534. Also the increased mica contents up to $18-27.3 \%$ of the rocks volume was found in the micaceous kimberlite breccia. The increased contents of amphiboles were detected in the epiclastic and volcanic-sedimentary crater facies rocks. The high concentrations of the kimberlite indicator minerals are characteristic for the gravelstons and sandstones from the upper part of the crater facies section. Garnet-pyroxene intergrowths were regularly found within the granulometric classes of heavy mineral concentrate that larger than $0.5 \mathrm{~mm}$. Monocline pyroxenes are represented by the prism shape diopside (chromediopside). Chromediopside contain more than 2 wt.\% of chrome that detect the presence of the yuriitic component $\left(\mathrm{NaCrSi}_{2} \mathrm{O}_{6}\right)$. Chromeless clinopyroxene with increased $\mathrm{Al}_{2} \mathrm{O}_{3}$ ? $\mathrm{Na}_{2} \mathrm{O}$ contents and low $\mathrm{CaO}$ and $\mathrm{MgO}$ contents (presence of the jadeite component) is also present in the kimberlites and it's an analogue to the omphacite from the $\mathrm{Mg}-\mathrm{Fe}$ eclogites. Clinopyroxene crystals touching with biotite and hornblende were found in the autolith breccias. Pyrope is represented by the three colored varieties depend on the $\mathrm{Cr}_{2} \mathrm{O}_{3}$ content: 1) violet and deep-red-violet (prevail), 2) red and orange-red, 3) orange and yelloworange. The increased (more than 10\%) quantity of the chrome-enriched knorringite-bearing pyropes that correlated with the diamond-bearing properties of 
kimberlites is noticed. Their composition is the same with pyropes - crystals in touch with the diamonds and inclusion in diamonds of the lerzolite associations. Abundant picroilmenite, whose content is sometimes more than $5 \%$ of the rocks volume, is present. Two groups of ilmenites can be distinct according to its chemical composition. The first is characterized by low contents of $\mathrm{MgO}$ (less than 6 wt.\%), $\mathrm{TiO}_{2}$ (less than 45 wt.\%) ? ? $\mathrm{r}_{2} \mathrm{O}_{3}$ (less than 1.6 wt.\%) with increased $\mathrm{Fe}_{2} \mathrm{O}_{3}$ (more than $20 \mathrm{wt} . \%$ ) contents. The second group characterized by increased $\mathrm{MgO}$ contents, more than 8 wt. $\%, \mathrm{TiO}_{2}-$ more than 45 wt. $\%$ ? $\mathrm{Cr}_{2} \mathrm{O}_{3}$ more than 1.6 wt.\%, with low $\mathrm{Fe}_{2} \mathrm{O}_{3}$ contents up to 18.7 wt.\%. The picroilmenite composition is high in chrome contents and it is an analogue to that of ilmenites from the mantle xenoliths and megacrysts. On their $\mathrm{MgO}$ contents it corresponds to paramagnetic ilmenites with increased content of geikielite solid solution. The highest contents of the coarse picroilmenite grains (more than $5 \mathrm{~mm}$ ) were found from the crater facies gravelstones. Rare chrome -spinel crystals that often occur as intergrowth with garnets and clinopyroxenes are close in chemical compositions to high-chrome spinels of the high Ti contents lherzolite paragenesis.

\section{CONCLUSIONS}

Overall, kimberlite diatremes with preserved crater part are characteristic for the Lunda-Norte Province (northeastern Angola) and it's caused by smallscale postkimberlite erosion of the territory. Kimberlites belong to Group I on their characteristic features. The Catoca pipe, with is the largest primary diamond deposits presently mined in Angola, could be regarded as the geological-petrographic model for the diatremes of province. The contents and associations of the indicator kimberlite minerals with knorringite- bearig pyropes and the crystal morphology characteristics of diamonds themselves are regarded as the diamond concentration indexes of rocks. Heterogeneous kimberlite rocks of the pipe are different in their petrological and geochemical properties.

\section{REFERENCES}

Araujo A.G, Perevalov O., Jukov R. e out., 1988. República Popular de Angola. Carta geologica de Angola, 1:1000000.: Luanda, Instituto Nacional de Geologia.

Araujo A.G., Perevalov O., Guimarães F.R. e out., 1988. República de Angola. Carta de recursos minerais, 1: 1000000.: Luanda, Instituto Geologico de Angola.

Bardet, M.G., 1973. Geologie du diamant: Volume 2: Gisements de diamante d'Afrigue: Mémoir, BRGM 83, Paris, $229 \mathrm{p}$
Boyd, F.R. and Danchin, R.V., 1980. Lherzolites, eclogites and megacrysts from some kimberlites of Angola: American Journal of Sciense, 280A, 528-549.

Clement C.R., Skinner E.M.W., 1985. Textural-genetic classifications of kimberlites /trans/ Geol. Soc. S. Afr. 88, 403-409.

Janse, A.J.A., 1995. A history of diamond sources in Africa: Part I: Gems and Gemology, 228-255.

Krutchkov A., Antoniuk B., Chipoio Bonifacio e out., 2000. Chamine kimberlitica de Catoca. Geologia, composição geologica das rochas e caracteristica dos diamantes: Luanda, GEO-Luanda - 2000 Internacional Conference.

Mitchell R.H., 1986. Kimberlites: Minerology, Geochemistry and Petrology. New York: Plenum Press, 442 p.

Reis, B.,1972. Preliminary note on the distribution and tectonic control of kimberlites in Angola: $24^{\text {th }}$ Internatinal Geological Congress, Section 4, 276-281.

Scott Smith B.H., 1992. Contrasting Kimberlites and Lamproites. Exploration and Mining Geology. 1, 371381.

Contact: A.Ya. Rotman, YaNIGP TsNIGRI ALROSA Co. Ltd, Chernyshevsky Street 7, Mirny, 678170, Russia, E-mail: rotman@cnigri.alrosa-mir.ru; arotman@mail.ru 